\title{
OECD 2006년도 \\ 공적개발원조 잠정통계
}

$\mathrm{OECD}$ 사무국은 2007. 4.3 개발원조위원회(DAC) 고위급회의 개최 계기에 2006년도 OECD DAC 회 원국의 개발원조 실적 잠정통계를 발표하였음

\section{I. 주요 내용}

- OECD 개발원조위원회(DAC) 22 개 회원국의 2006년도 순 원조액(Net ODA)은 1,039억불 로 2005 년도 대비 $5.1 \%$ 감소(2005년도 1,068 억불)

- GNI 대비 원조액은 0.30\%로 2005년의 $0.33 \%$ 보다 감소

- 주요 공여국의 2006 년도 개발원조의 감소는 2005년에 이루어진 이라크 및 나이지리아에 대한 대규모 부채탕감에 기인

- 2006년도 통계에는 192억불의 부채탕감이 포함되어 있으며, 부채탕감을 제외할 경우
$1.8 \%$ 감소

- 우리나라의 경우 2006년 ODA는 4.47억불로 2005년도 7.52 억불에 비해 $44.6 \%$ 감소하였 으며 GNI 대비 $0.05 \%$ 기록 (2005년도 0.1\%) - 다자원조기구에 대한 2005년도 대규모 공여 에 기인

- 유엔의 GNI $0.7 \%$ 목표를 달성한 국가는 스웨 덴, 룩셈부르크, 노르웨이, 네덜란드, 덴마크 이며, 최대 공여국은 미국, 영국, 일본, 프랑 스, 독일 순

- 2007년도에도 DAC 회원국의 ODA는 부채탕 감이 완료됨에 따라 다소 감소할 전망이나, 주 요 공여국들이 $\mathrm{ODA}$ 증액 공약을 실천하게 되 어 부채탕감을 제외한 $\mathrm{ODA}$ 는 증가할 전망 


\section{II. 상세 내용}

\section{1. 주요 공여국 ODA 현황}

- 미국은 227 억불 기록하여 전년도 대비 $20 \%$ 하락하였으며 (GNI 대비 0.17\%로 하락), 이는 부채탕감액 감소에 기인함

- 일본은 116 억불(GNI 의 $0.25 \%$ )을 기록하여 $9.6 \%$ 하락함

- $\mathrm{EU} \mathrm{DAC}$ 회원국 15 개국의 총 ODA는 589 억 불로 2005 년 대비 $2.7 \%$ 증가하였으며, GNI 대비 $0.43 \%$ 로서 $\mathrm{EU}$ 전체 회원국의 목표치인 $0.39 \%$ 를 초과하였음

- 2006년도 ODA 증가는 주로 부채탕감에 기인

- $\mathrm{EC}(\mathrm{EU}$ 집행위)의 $\mathrm{ODA}$ 는 102 억불이며 $5.7 \%$ 증가

\section{2. 향후 전망}

- 2007년도 DAC 회원국의 ODA는 나이지리아 및 이라크에 대한 부채탕감이 2006년도에 완 료됨에 따라 다소 감소할 전망이나, 주요 공 여국들이 $\mathrm{ODA}$ 증액 공약을 실천하기 시작함 에 따라 부채탕감을 제외한 $\mathrm{ODA}$ 는 증가할 전 망임

- EU는 2010년 까지 회원국 ODA를 GNI의 $0.56 \%$ 까지 증액하고, 특히 DAC 회원국에 대해서는 최소한 $0.51 \%$ 로 증액토록 2005년 에 합의

- 호주는 2010년까지 40 억 호주달러로 2 배 증 액을 발표하였고, 일본은 2005-2009년 기간 중 총100억 달러 증액 예정

[자료 : 주오이시디대표부 ] 